\title{
An Insight into Transfer Hydrogenation Reactions Catalysed by Iridium(III) Bis- $N$-Heterocyclic Carbenes
}

\author{
Nestor García, ${ }^{[a]}$ E. A. Jaseer, ${ }^{[a]}$ Julen Munarriz, ${ }^{[b]}$ Pablo J. Sanz Miguel, ${ }^{[c]}$ \\ Victor Polo, ${ }^{[b]}$ Manuel Iglesias, ${ }^{*[c]}$ Luis A. Oro ${ }^{*[a, c]}$
}

[a] Centre of Research Excellence in Petroleum Refining, King Fahd University of Petroleum \& Minerals (KFUPM), Dhahran 31261 (Saudi Arabia).

[b] Departamento Química Física - Instituto de Biocomputación y Física de Sistemas Complejos (BIFI), Universidad de Zaragoza, 50009 Zaragoza (Spain).

[c] Departamento Química Inorgánica - ISQCH, Universidad de Zaragoza - CSIC, 50009 Zaragoza (Spain),E-mail:miglesia@unizar.es; oro@unizar.es.

\begin{abstract}
A variety of $\left[\mathrm{M}(\mathrm{L})_{2}\left(\mathrm{~L}^{\prime}\right)_{2}\left\{\kappa \mathrm{C}, \mathrm{C}^{\prime}-\mathrm{bis}(\mathrm{NHC})\right\}\right] \mathrm{BF}_{4}$ complexes $\left(\mathrm{M}=\mathrm{Rh}\right.$ or $\mathrm{Ir} ; \mathrm{L}=\mathrm{CH}_{3} \mathrm{CN}$ or wingtip group; $\mathrm{L}^{\prime}=\mathrm{I}^{-}$or $\mathrm{CF}_{3} \mathrm{COO}^{-} ; \mathrm{NHC}=\mathrm{N}$-heterocyclic carbene) have been tested as precatalysts for the transfer hydrogenation of ketones and imines. The conversions and TOF's obtained are closely related to the nature of the ligand system and metal centre, more strongly coordinating wingtip groups yielding more active and recyclable catalysts. Theoretical calculations at the DFT level support a classic stepwise metal-hydride pathway against the concerted Meerwein-PonndorfVerley (MPV) mechanism. The calculated catalytic cycle involves a series of ligand rearrangements due to the high trans effect of the carbene and hydrido ligands, which are more stable when situated in mutual cis positions. The reaction profiles obtained for the complexes featuring an iodide or a trifluoroacetate in one of the apical positions agree well with the relative activity observed for both catalysts.
\end{abstract}

\section{Introduction}

The hydrogenation of organic molecules, in particular the reduction of imines and ketones, is a fundamental reaction in industrial synthetic chemistry. ${ }^{[1]}$ Transfer hydrogenation reactions have emerged as an alternative to classic catalytic hydrogenation for a variety of organic substrates. ${ }^{[2]}$ Besides, this reduction procedure circumvents the need for pressurised systems and its associated safety issues by employing solid or liquid hydrogen donors instead of molecular hydrogen.

In this regard, organometallic NHC complexes ( $\mathrm{NHC}=N$-heterocyclic carbene) have shown remarkable activities in the transfer hydrogenation reaction. ${ }^{[3]}$ An interesting class of pre-catalysts are those reported by Crabtree and co-workers based on bis-NHC ligands. These iridium(III) complexes of general formula $\left[\operatorname{Ir}(\right.$ bis-NHC $\left.)(\mathrm{OAc}) \mathrm{I}_{2}\right]$ are air stable and moisture insensitive compounds and show activities that are very dependent on the NHC's wingtip groups. ${ }^{[4]}$ The catalytic cycle has been proposed to follow the "hydridic route" expected for transition-metal catalysed hydrogen transfers. ${ }^{[5]}$ The Meerwein-Ponndorf-Verley (MPV) mechanism, ${ }^{[6]}$ which involves a concerted hydride transfer to the substrate directly from the alkoxy ligand via a sixmembered transition state, was discarded based on data obtained from a variation of the deuteration experiments reported by Pàmies and Bäckvall. ${ }^{[7]}$ Although these results are not conclusive, several other experimental evidences suggest a metal-hydride route as a more plausible mechanism. Namely, (i) the reactivity rates of substituted acetophenones do not compare well with those observed for MPV reactions; (ii) the reduction reaction is considerably faster than its related oxidation, which deviates from the expected similar reaction rates for MPV reduction-Oppenhauer 
oxidation reactions; ${ }^{[8]}$ finally, (iii) the reported complexes catalyse the hydrogenation of allylbenzene, this being unlikely to occur via an MPV mechanism.

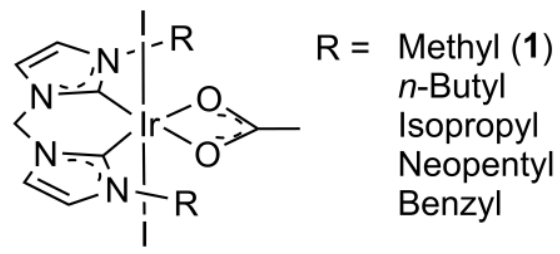

Figure 1. Bis-NHC iridium transfer hydrogenation catalysts reported by Crabtree et. al..

Recently, we have reported a variety of $\left[\mathrm{M}(\mathrm{L})_{2}\left(\mathrm{~L}^{\prime}\right)_{2}\left\{\kappa \mathrm{C}, \mathrm{C}^{\prime}-\operatorname{bis}(\mathrm{NHC})\right\}\right] \mathrm{BF}_{4}(\mathrm{M}=\mathrm{Rh}$ or $\mathrm{Ir} ; \mathrm{L}=$ $\mathrm{CH}_{3} \mathrm{CN}$ or wingtip group; $\mathrm{L}^{\prime}=\mathrm{I}^{-}$or $\mathrm{CF}_{3} \mathrm{COO}^{-}$; $\mathrm{NHC}=\mathrm{N}$-heterocyclic carbene) complexes that showed good activities for the hydrosilylation of alkynes, as well as for the methanolysis and hydrolysis of hydrosilanes. ${ }^{[9]}$ The different coordination ability and steric hindrance of the $\mathrm{N}$ substituents at the NHC's have proved to be key factors that determine the stability and reactivity of the catalyst. Moreover, the nature of the apical ligands has demonstrated to play a crucial role on the selectivity of the hydrosilylation of terminal alkynes. When the iodide ligands in the parent $\left[\mathrm{Rh}(\mathrm{I})_{2}\left\{\kappa \mathrm{O}, \mathrm{C}, \mathrm{C}^{\prime}, \mathrm{O}^{\prime}-\right.\right.$ bis $\left.\left.(\mathrm{NHC})\right\}\right] \mathrm{BF}_{4}$ complex were replaced by trifluoroacetates, a drastic selectivity change, from the anti-Markovnikov anti-addition product to the Markovnikov addition product, was observed. ${ }^{[9 \mathrm{~d}]}$

Here we report on the catalytic activity in transfer hydrogenation of $\operatorname{Ir}(\mathrm{III})$ complexes featuring methylene bridged bis-NHC ligands that contain wingtip groups with different coordination ability and steric impact. Moreover, we studied the influence of (i) exchanging one of the apical iodides by a more labile trifluoroacetate ligand, and (ii) the nature of the metal centre on the activity of the resulting catalysts, namely $\operatorname{Ir}(\mathrm{III})$ vs $\mathrm{Rh}$ (III). Finally, a detailed mechanistic study that discloses the hitherto unknown intermediate species as well as the role played by the ancillary ligands is proposed based on DFT calculations and experimental data.

\section{Results and Discussion}

Complexes 2-7 were tested as catalyst precursors for the transfer hydrogenation of a range of ketones and imines in order to investigate the effect of modifying the ligand system, i.e. $N$ substituents or apical ligands, and the nature of the metal centre in the activity of Ir or Rh(III) bis(NHC) complexes. Complexes 3-6 (Figure 2) were previously reported by us ${ }^{[9]}$ while the preparation of $\mathbf{2}$ and $\mathbf{7}$ is described in this work (vide infra).

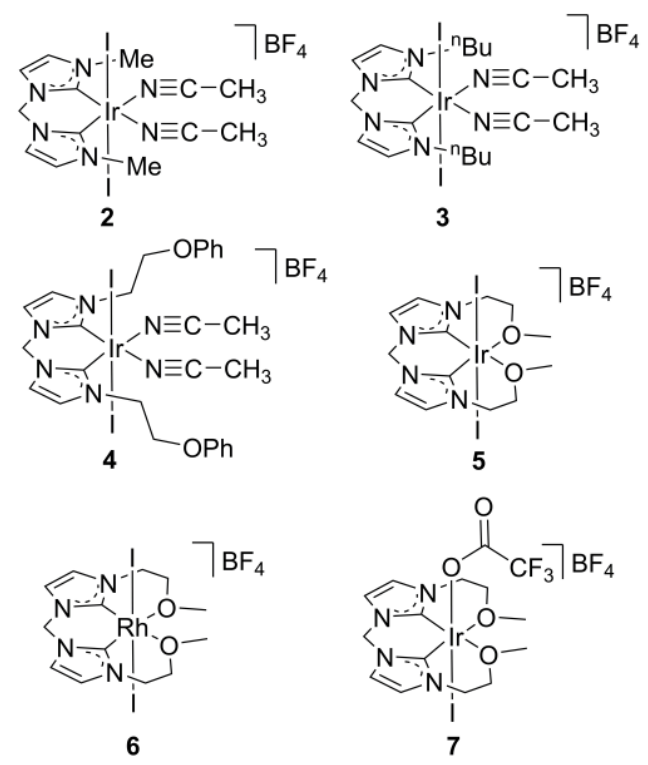

Figure 2. Complexes tested in this work as transfer hydrogenation catalysts. 
Synthesis and characterization of $\left[\operatorname{Ir}\left(\mathrm{CH}_{3} \mathrm{CN}\right)_{2}(\mathrm{I})_{2}\left\{\boldsymbol{\kappa}^{2} C, C^{\prime}-\operatorname{bis}\left(\mathrm{NHC}^{\mathrm{Me}}\right)\right\}\right] \mathrm{BF}_{4} \quad\left(\mathrm{NHC}^{\mathrm{Me}}=\right.$ methylenebis $\left(N\right.$-methyl)imidazole-2-ylidene) $\quad$ (2). Complex $\quad\left[\operatorname{Ir}\left(\mathrm{CH}_{3} \mathrm{CN}\right)_{2}(\mathrm{I})_{2}\left\{\kappa^{2} C, C^{\prime}-\right.\right.$ bis $\left.\left(\mathrm{NHC}^{\mathrm{Me}}\right)\right\} \mathrm{BF}_{4}(\mathbf{6})$ was obtained as an orange solid in $78 \%$ yield by treatment of $\mathbf{1}$ with 1.1 equivalents of $\mathrm{HBF}_{4} \cdot \mathrm{Et}_{2} \mathrm{O}$ at $0{ }^{\circ} \mathrm{C}$ in dry dichloromethane, followed by addition of excess acetonitrile (Scheme 1). The protonation and concomitant dissociation of the acetato ligand was monitored by the disappearance of the $\mathrm{CH}_{3} \mathrm{COO}$ protons in ${ }^{1} \mathrm{H}-\mathrm{NMR}$.

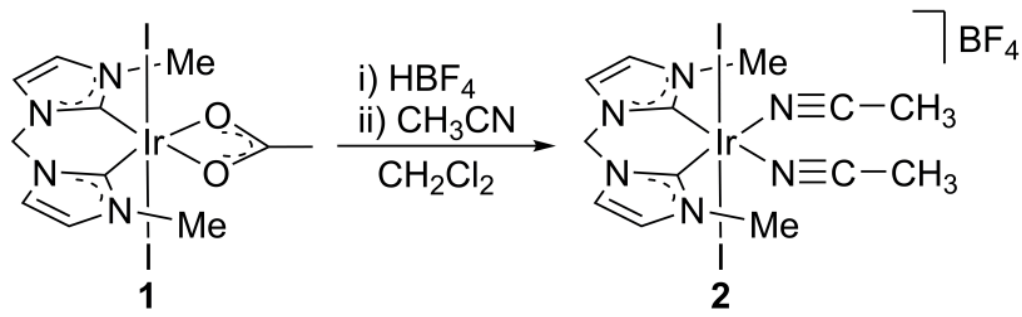

Scheme 1. Preparation of complex 2.

The ${ }^{1} \mathrm{H}$ NMR spectra of complex 2 in $\mathrm{CD}_{3} \mathrm{CN}$ shows two doublets $(2.0 \mathrm{~Hz})$ that correspond to the $\mathrm{CH}$ 's of the NHC rings at $\delta$ values of 7.31 and $7.20 \mathrm{ppm}$. The protons of the methylene bridge and the $N$-methyl groups appear as a singlet at $\delta$ values of 6.39 and $4.04 \mathrm{ppm}$, respectively. A singlet at a $\delta$ value of $1.96 \mathrm{ppm}$ that integrates ca. 6 protons could be assigned to free acetonitrile, probably due to displacement of the coordinated acetonitrile ligands by the deuterated solvent. The low solubility of 2 in $\mathrm{CD}_{2} \mathrm{Cl}_{2}, \mathrm{CDCl}_{3}$ or even acetone- $\mathrm{d}_{6}$ precluded its characterization in less coordinating solvents. The most characteristic signal in the ${ }^{13} \mathrm{C}\left\{{ }^{1} \mathrm{H}\right\}$ NMR spectra is that corresponding to the carbene carbons at a $\delta$ value of $128.0 \mathrm{ppm}$. The main text of the article should appear here with headings as appropriate.

Synthesis and characterization of $\left[\operatorname{Ir}\left(\kappa O-\mathrm{CF}_{3} \mathrm{COO}\right)(\mathrm{I})\left\{\kappa^{4} O, C, C^{\prime}, O^{\prime}-\mathrm{bis}\left(\mathrm{NHC}^{\mathrm{OMe}}\right)\right\}\right] \mathrm{BF}_{4}$ $\left(\mathrm{NHC}^{\mathrm{OMe}}=\right.$ methylenebis $(\boldsymbol{N}$-2-methoxyethyl)imidazole-2-ylidene $\left.)\right)(7)$. Complex 7 was prepared by treating of 5 with 1 equivalent of silver trifluoroacetate at room temperature in acetone. The reaction entails the abstraction of one of the iodides in $\mathbf{5}$. Subsequently, the vacant coordination site thus generated is occupied by a $\kappa O-\mathrm{CF}_{3} \mathrm{COO}$ ligand to give complex $\mathbf{7}$ as an air-stable, brightorange solid in good yields (Scheme 2). The ${ }^{1} \mathrm{H}$ NMR spectrum of $\mathbf{7}$ is similar to that of $\mathbf{5}$. The most significant differences in the ${ }^{1} \mathrm{H}$ NMR spectrum of 7 are the AB system centred at $\delta$ values of 6.78 and $6.66 \mathrm{ppm}\left({ }^{2} J_{\mathrm{H}-\mathrm{H}}=13 \mathrm{~Hz}\right)$ that corresponds to the diasterotopic protons of the methylene group bridging the two NHC rings, and the multiplet from 4.75 to $4.50 \mathrm{ppm}$ due to the diastereotopic methylenic protons of the wingtip groups $\left(\mathrm{NCH}_{2}\right.$ and $\left.\mathrm{OCH}_{2}\right)$. The ${ }^{13} \mathrm{C} \mathrm{NMR}$ spectra show a singlet at a $\delta$ value of $120.2 \mathrm{ppm}$ that can be assigned to the carbene carbon atoms coordinated to the iridium centres and two quartets corresponding to the $\mathrm{CF}_{3} \mathrm{COO}^{-}$ligand at $\delta$ values of $161.0\left({ }^{2} \mathrm{~J}_{\mathrm{C}-\mathrm{F}}=\right.$ $40 \mathrm{~Hz})$ and $113.6\left({ }^{1} \mathrm{~J}_{\mathrm{C}-\mathrm{F}}=292 \mathrm{~Hz}\right) \mathrm{ppm}$. The ${ }^{19} \mathrm{~F}$ NMR presents two peaks at $\delta$ values of -74.7 and $151.4 \mathrm{ppm}$ that can be assigned to the $\mathrm{BF}_{4}{ }^{-}$counteranion and the $\mathrm{CF}_{3} \mathrm{COO}^{-}$ligand, respectively.

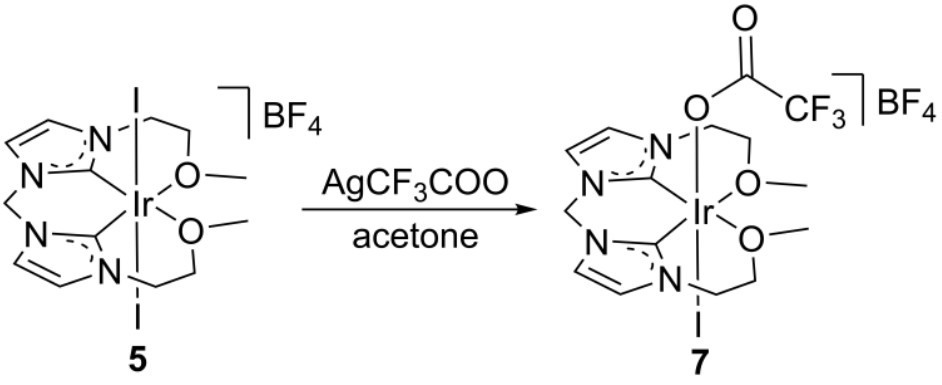

Scheme 2. Preparation of complex 7. 
Noteworthy, when two equivalents of silver salt were added to 5 in order to prepare the bis(iodido) complex an unidentified mixture of complexes was obtained.

Suitable crystals of 7 were grown by slow diffusion of diethyl ether into a saturated acetone solution. The molecular structures obtained by single crystal X-ray diffraction analysis (Figure 3) confirm the expected coordination of the trifluoroacetato ligand at the axial position. The asymmetric unit of $\mathbf{7}$ encloses two crystallographically different cations $\left[\operatorname{Ir}\left(\kappa O-\mathrm{CF}_{3} \mathrm{COO}\right)(\mathrm{I})\right.$ $\left\{\kappa^{2} O, C, C^{\prime}, O^{\prime}\right.$-bis $\left.\left.\left(\mathrm{NHC}^{\mathrm{OMe}}\right)\right\}\right]^{+}$and their respective $\mathrm{BF}_{4}^{-}$anions. Geometry of both enantiomers is roughly identical. Equatorial coordination of the tetratopic bis $\left(\mathrm{NHC}^{\mathrm{OMe}}\right)$ ligand does not display notable differences in comparison to analogous complexes. ${ }^{[9 \mathrm{~b}]} \mathrm{A}$ difference regarding the trans influence is observable in the $\mathrm{Ir}-\mathrm{I}$ bond lengths of the $\mathrm{I}-\mathrm{Ir}-\mathrm{OOCCF}_{3}$ system of 7 (Ir1-I1, 2.6335(5) $\AA$; Ir2-I2, 2.6372(5) $\AA$ ), which are significantly shorter when compared to the corresponding I-Ir-I frame in an analogous complex ${ }^{[9 a]}(\operatorname{Ir} 1-I 1,2.6750(3) \AA$; Ir1-I2, 2.6614(3) $\AA$ ).
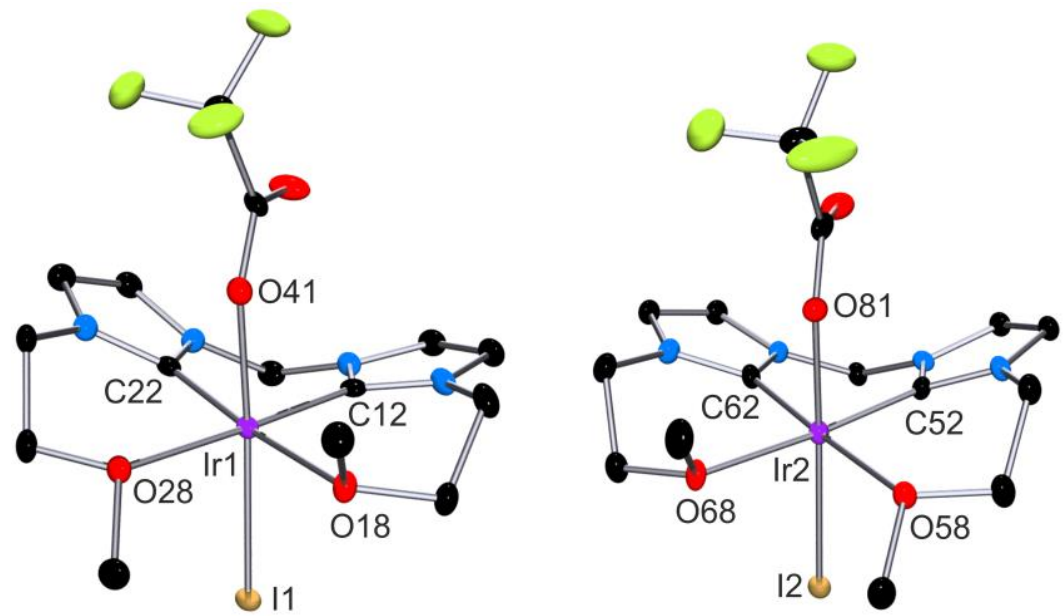

Figure 3. View of cations of 7. Selected bond distances $[\AA]$ and angles $\left[^{\circ}\right]$ of cation 7: $\operatorname{Ir} 1-\mathrm{C} 12$ 1.959(7), Ir2-C52 1.948(6), Ir1-C22 1.931(7), Ir2-C62 1.935(7), Ir1-O18 2.189(5), Ir2-O58, 2.197(5), Ir1-O28 2.186(4), Ir2-O68 2.185(4), Ir1-O41 2.054(5), Ir2-O81 2.061(5), Ir1-I1 2.6335(5), Ir2-I2, 2.6372(5), C22-Ir1-C12 88.3(3), C62-Ir2-C52 88.3(3), C12-Ir1-O41 95.8(2), C52-Ir2-O81 91.4(2), C12-Ir1-O18 91.7(2), C52-Ir2-O58 90.7(2), C12-Ir1-I1 89.15(18), C52Ir2-I2 92.3(2), O18-Ir1-I1 91.64(13), O58-Ir2-I2 92.43(13), O41-Ir1-I1 174.71(13), O81-Ir2-I2 $175.42(13)$.

Catalytic studies. Initial catalytic studies aimed at comparing the effect of two sterically similar wingtip groups with and without a coordinating atom embedded in its structure. In this regard, when complex 3, which features butyl groups $\left(-\mathrm{CH}_{2} \mathrm{CH}_{2} \mathrm{CH}_{2} \mathrm{CH}_{3}\right)$ as $N$-substituents, is weighed against 5, where an oxygen atom substitutes one of the methylene groups $\left(-\mathrm{CH}_{2} \mathrm{CH}_{2} \mathrm{OCH}_{3}\right)$, a remarkable enhancement of the activity is observed for the latter groups (for example see Entry 2 vs Entry 5 in Table 1). In this regard, heteroditopic NHC ligands have proved highly efficient ancillary ligands for transfer hydrogenation catalysis. ${ }^{[10]}$

A bis-NHC ligand featuring more labile N-substituents than those in $\mathbf{5}$, namely ethyl phenyl ethers (complex 4), ${ }^{[8]}$ was explored in order to shed light on whether a weaker stabilization of the metal centre would render a more active catalyst. Conversely, a screening of the activity of complex $\mathbf{4}$ for a variety of ketones (Table 1) and imines (Table 2) shows, in general, that its activity is somewhere between $\mathbf{3}$ and $\mathbf{5}$. Yet, it is worth emphasising the importance of the stabilisation of the metal centre by the wingtip groups, which is further supported by the fact that $\mathbf{4}$ is more reactive than $\mathbf{3}$ except for the reaction with $p$-MeO-acetophenone (entries 19-20) and, particularly, $p$-Me-acetophenone (entries 26-27). 
Table 1. Transfer hydrogenation of ketones.

\begin{tabular}{|c|c|c|c|c|c|}
\hline Entry & Substrate & Cat. & $\begin{array}{c}\mathrm{T} \\
\text { (h) }\end{array}$ & Conv.(\%) & $\mathrm{TOF}_{1 / 2}$ \\
\hline 1 & & 2 & 0.5 & 92 & 242 \\
\hline 2 & & 3 & 0.75 & 94 & 203 \\
\hline 3 & & 4 & 0.5 & 98 & 422 \\
\hline 4 & & 5 & 0.33 & 98 & 451 \\
\hline 5 & & 6 & 23 & 51 & 2 \\
\hline 6 & & 7 & 0.33 & 90 & 377 \\
\hline 7 & & 2 & 5 & 98 & 97 \\
\hline 8 & & 3 & 3 & 92 & 161 \\
\hline 9 & & 4 & 3 & 96 & 240 \\
\hline 10 & & 5 & 1 & 99 & 388 \\
\hline 11 & & 6 & 7 & 97 & 88 \\
\hline 12 & & 7 & 1 & 98 & 364 \\
\hline 13 & & 2 & 5 & 96 & 58 \\
\hline 14 & & 3 & 3 & 94 & 66 \\
\hline 15 & & 4 & 3 & 98 & 615 \\
\hline 16 & & 5 & 1 & 99 & 274 \\
\hline 17 & & 7 & 1.5 & 97 & 123 \\
\hline 18 & & 2 & 23 & 78 & 17 \\
\hline 19 & & 3 & 7 & 83 & 38 \\
\hline 20 & & 4 & 11 & 84 & 33 \\
\hline 21 & & 5 & 7 & 77 & 53 \\
\hline 22 & & 7 & 7 & 80 & 28 \\
\hline 23 & & 2 & 23 & 90 & 40 \\
\hline 24 & & 3 & 5 & 93 & 127 \\
\hline 25 & & 4 & 7 & 89 & 54 \\
\hline 26 & & 5 & 1.5 & 95 & 228 \\
\hline 27 & & 7 & 7 & 89 & 64 \\
\hline 28 & & 2 & 3 & 94 & 55 \\
\hline 29 & & 3 & 3 & 96 & 77 \\
\hline 30 & & 4 & 2 & 96 & 111 \\
\hline 31 & & 5 & 0.5 & 82 & 205 \\
\hline 32 & & 7 & 2 & 97 & 115 \\
\hline
\end{tabular}

Conditions: catalyst $(0.01 \mathrm{mmol})$, ketone $(1 \mathrm{mmol})$, base $(t \mathrm{BuOK}, 0.05 \mathrm{mmol}), i \mathrm{PrOH}(5 \mathrm{~mL}), 80^{\circ} \mathrm{C}$.

Conversion determined by GC.

The steric protection of the metal centre is reduced to a minimum by introducing methyl substituent on the NHC (2). Complex 2 is the least active catalysts of the series (2-7); however, it is not clear whether this is due to the reduced steric shielding of the active site or to the low solubility of the complex in $i \mathrm{PrOH}$.

Rhodium complex 6 was tested in order to assess the influence of the metal centre on the catalytic activity. Analogously to what has been reported previously for NHC complexes, ${ }^{[3,12,10 \mathrm{~d}]} \mathbf{6}$ is 
markedly less active than its iridium counterpart 5, the latter being the most active complex presented in this work.

Table 2. Transfer hydrogenation of imines.

\begin{tabular}{|c|c|c|c|c|c|}
\hline Entry & Substrate & Cat. & $\begin{array}{c}\mathrm{T} \\
(\mathrm{h})\end{array}$ & Conv.(\%) & $\mathrm{TOF}_{1 / 2}$ \\
\hline 1 & & 2 & 23 & 90 & 57 \\
\hline 2 & & 3 & 7 & 96 & 57 \\
\hline 3 & & 4 & 5 & 95 & 153 \\
\hline 4 & & 5 & 2 & 91 & 194 \\
\hline 5 & & 6 & 30.5 & 78 & 7 \\
\hline 6 & & 7 & 3 & 96 & 123 \\
\hline 7 & & 2 & 24 & 47 & 2 \\
\hline 8 & & 3 & 23 & 55 & 2 \\
\hline 9 & & 4 & 23 & 70 & 10 \\
\hline 10 & & 5 & 23 & 62 & 14 \\
\hline 11 & & 2 & 23 & 86 & 8 \\
\hline 12 & & 3 & 23 & 52 & 3 \\
\hline 13 & & 4 & 7 & 93 & 60 \\
\hline 14 & Mac & 5 & 7 & 88 & 18 \\
\hline 15 & & 2 & 23 & 38 & - \\
\hline 16 & & 3 & 23 & 91 & 10 \\
\hline 17 & & 4 & 23 & 80 & 22 \\
\hline 18 & & 5 & 7 & 94 & 26 \\
\hline
\end{tabular}

Conditions: catalyst $(0.01 \mathrm{mmol})$, imine $(1 \mathrm{mmol})$, base $(t \mathrm{BuOK}, 0.05 \mathrm{mmol}), i \mathrm{PrOH}(5 \mathrm{~mL}), 80^{\circ} \mathrm{C}$. Conversion determined by GC.

Furthermore, the catalytic activity of complexes $\mathbf{5}$ and $\mathbf{7}$ was compared with the intention of studying the influence of the apical ligand. According to the monohydride mechanism expected for this type of complexes, the catalytic cycle should be initiated by the attack of the isopropoxide anion to the metal centre. Two possible coordination positions can be envisaged for the $i \mathrm{PrO}^{-}$, equatorial or axial, i.e. trans or cis to one of the carbene carbons, respectively. The next step would entail the formation of a hydrido ligand, which, again, can take place at the any of the two positions mentioned above. Therefore, if the attack of $i \mathrm{PrO}^{-}$happened at the apical position the reaction rate should be improved by the presence of the more labile trifluoroacetato ligand in 7. On the contrary, a significant reduction of the catalytic activity is observed. On these grounds, the coordination of the isopropoxide probably occurs at one of the equatorial positions since the presence of a more labile ligand $\left(\mathrm{CF}_{3} \mathrm{COO}^{-}\right)$should increase, and never reduce, the catalytic activity, thanks to a more facile access of the isopropoxide to the metal centre. This behaviour would be in agreement with the higher trans effect expected for NHC ligands compared to iodides, which strongly labilizes the equatorial ligands, thus favouring the attack of $i \mathrm{PrO}^{-}$at these positions.

A plausible explanation for this decrease in the activity of the catalyst may be that the $\beta$-hydrogen elimination step is somehow hampered by the trifluoroacetato ligand. Therefore, initial formation of the hydride at the apical position can be safely discarded because the presence of the iodide, instead of the more labile trifluoroacetate, should obstruct this step while, in reality, the bis(iodide) complex $\mathbf{5}$ is significantly more active than $\mathbf{7}$.

Kinetic experiments performed with catalysts 2-7 for the transfer hydrogenation of cyclohexanone under the conditions described in table 1 are shown in Figure 4. The behaviour of the catalysts fits 
well the general trend observed for other substrates, with the exception of $\mathbf{2}$, which is slightly more active than $\mathbf{3}$ in this case.

The results described above suggest that the activity of the pre-catalysts may be closely related to the stability of the active species, as NHCs containing more strongly coordinating wingtip groups lead to better reaction rates. Figure 5 shows the conversions obtained by catalysts $\mathbf{2 - 5}$ for five consecutive uses in the transfer hydrogenation of cyclohexanone in 2-propanol.

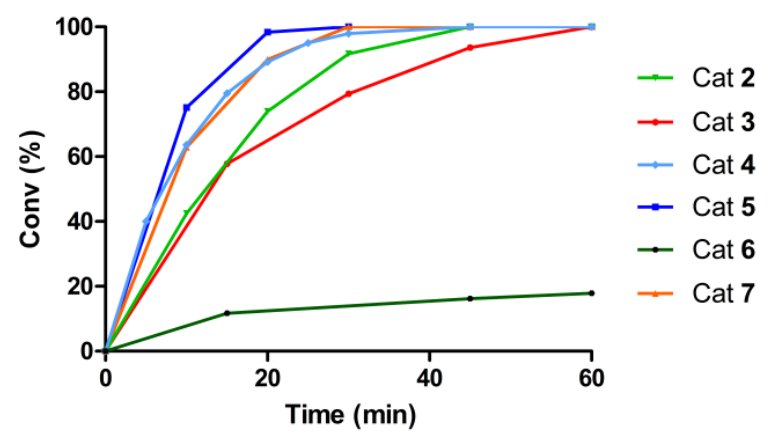

Figure 4. Activity of catalysts 2-7 in the hydrogenation of cyclohexanone.

The higher stability of $\mathbf{5}$ compared to that of $\mathbf{3}$ is supported by the better performance of the former throughout the recycling studies. The reduction of the steric protection exerted by the wingtip groups in $\mathbf{2}$ further decreases the activity of the catalyst upon successive cycles. Finally, complex $\mathbf{4}$ exhibits an unexpected behaviour, as a drastic activity loss is observed after the first use.

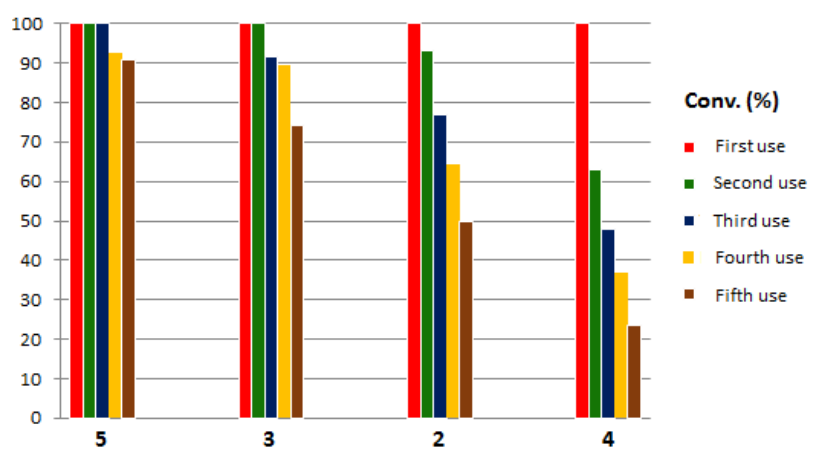

Figure 5. Recycling experiments performed with catalysts 2-5 (1 mol \%), $t \mathrm{BuOK}(5 \mathrm{~mol} \%)$ and cyclohexanone as substrate in 2-propanol at $80^{\circ} \mathrm{C}$.

Theoretical calculations and proposed catalytic cycle. The catalytic cycle reported by Crabtree et. al. for the transfer hydrogenation of ketones with the iridium bis(NHC) complexes presented in Figure 2 has been proposed to follow the monohydride mechanism, thus discarding a MPV type mechanism. Furthermore, it is generally accepted that metal complexes based on $\mathrm{Ru}, \mathrm{Mo}, \mathrm{Rh}$ and $\mathrm{Ir}$ operate by the monohydride route, ${ }^{[13]}$ although exceptions have been reported. ${ }^{[7,14]}$ In this work, a computational study using DFT calculations has been carried out using complexes $\mathbf{5}$ and $\mathbf{7}$ as models in order to clarify the mechanisms involved in this iridium(III) catalysed reaction and the species that determine the overall activation energy (Figure 6). At the outset of this study we considered that two main issues needed to be addressed. First of all, we set off to search for additional support that would confirm a metal-hydride mechanism, since MPV-type hydrogen transfer is also conceivable - the dissociation of the wingtip groups in complexes $\mathbf{5}$ and $\mathbf{7}$, or the acetonitrile ligands in $\mathbf{2 - 4}$, would generate two vacant coordination sites that may allow for the formation of the six-membered pericyclic transition state. Secondly, in the case that the former was, as proposed for related complexes, ${ }^{[4 a]}$ the most favourable mechanism, a detailed theoretical study would be undertaken in order to explain how and where the attack of the isopropoxide, the formation of the hydride and hydrogenation of the ketone occur. 
The Gibbs free energy profiles for both pathways are shown in Figure 6. Complexes 5 and 7 may dissociate one of the ether wingtip groups and coordinate the ${ }^{\mathrm{i}} \mathrm{PrO}^{-}$anion to yield neutral complex A. Decoordination of the second wingtip ether from the metal generates a vacancy cis to the isopropoxide at the metal that permits the formation of a hydride by $\beta$-elimination of the $\mathrm{C}-\mathrm{H}$ bond of the alkoxo ligand via transition state TSA/B. The energetic barrier for this step is very similar for catalysts $\mathbf{5}$ and 7, 11.0 and $12.2 \mathrm{kcal} \mathrm{mol}^{-1}$, respectively. Once the hydride intermediates (B) are formed, the isomerisation to $\mathbf{B}$ ' takes place due to the high trans effect of the hydride and the NHC ligand. Species $\mathbf{B}^{\prime}$ present the hydride trans to the iodide ligand and one of the carbenes trans to the iodido or trifluoroacetato ligand, thus leading to a stabilisation of 4.6 and $11.2 \mathrm{kcal} \mathrm{mol}^{-1}$, for $\mathbf{5}$ and $\mathbf{7}$, respectively. Interestingly, intermediate $\mathbf{B}^{\prime}$ is more strongly stabilised for catalyst $\mathbf{7}$ than for $\mathbf{5}$ due to the lower trans influence of the trifluoroacetato ligand compared to that of the iodide. Subsequently, the acetone ligand (formed after $\beta$-elimination) is replaced by the substrate (acetophenone) to give species $\mathbf{C}^{\prime}$, which results in an energetic stabilization of 3.9 and $0.8 \mathrm{kcal}$ $\mathrm{mol}^{-1}$ for $\mathbf{5}$ and $\mathbf{7}$, respectively.

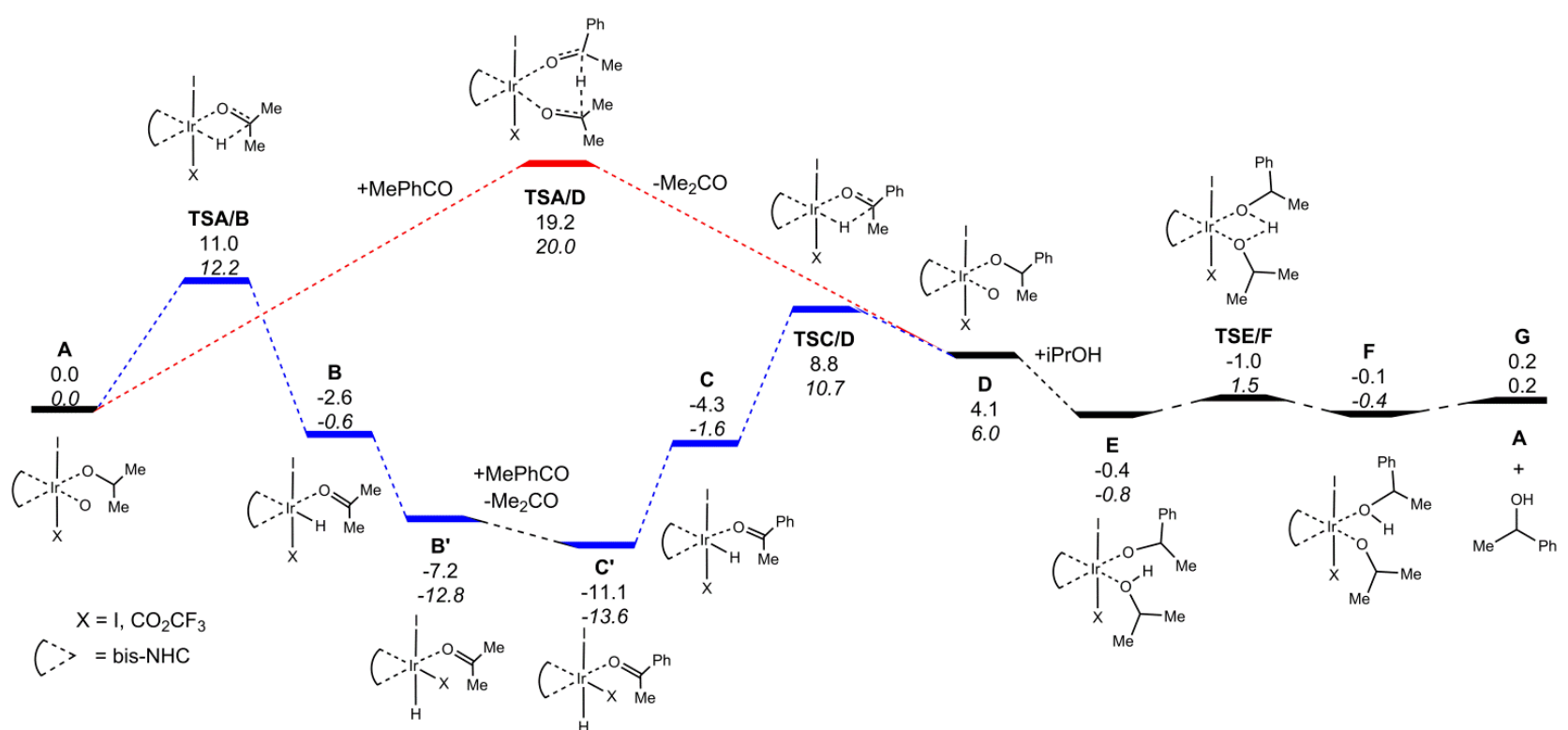

Figure 6. Gibbs free energy profile (in $\mathrm{kcal} \mathrm{mol}^{-1}$, relative to $\mathbf{A}$ and isolated molecules) for the transfer hydrogenation of acetophenone by 2-propanol catalyzed by 5 ( $\mathrm{X}=\mathrm{I}$, normal values) and $\mathbf{7}$ ( $\mathrm{X}=\mathrm{CF}_{3} \mathrm{COO}$, italic values).

Isomerisation to $\mathbf{C}$ is required in order to permit the migratory insertion of the acetophenone $\mathrm{C}-\mathrm{O}$ bond into the $\mathrm{Ir}-\mathrm{H}$ bond via transition states TSC/D (see Figure 7), which have relative energies of 8.8 and $10.7 \mathrm{kcal} \mathrm{mol}^{-1}$ for $\mathbf{5}$ and $\mathbf{7}$, respectively. Remarkably, direct migratory insertion from $\mathbf{C}^{\prime}$ leads to a less stable transition state and, consequently, to a higher activation energy for the overall process.

Finally, intermediate D undergoes the coordination of an ${ }^{i} \mathrm{PrOH}$ molecule that transfers the $-\mathrm{OH}$ proton to the alkoxo ligand in a concerted manner through transition state TSD/E to give the corresponding alcohol (1-phenylethanol) and the active species (A).

Alternatively, the concerted MPV mechanism takes place via TSA/D (see Figure 7) presenting a relative energy of 19.2 and $20.0 \mathrm{kcal} \mathrm{mol}^{-1}$ for $\mathbf{5}$ and $\mathbf{7}$, respectively. The energetic barrier is substantially higher than that found for the monohydride mechanism and, therefore, can be safely discarded.

Inspection of the calculated energetic profile for the catalytic cycle reveals that hydride species are exergonic with respect the catalyst and the reactants. The overall activation energies are determined

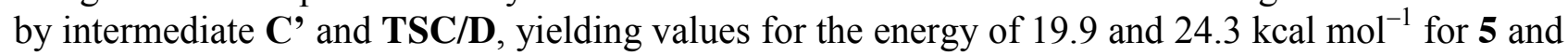
7, respectively. Therefore, higher TOF values are expected for $\mathbf{5}$ due to the higher stability of the hydride intermediates rendered by catalyst 7 , which is in agreement with experimental results. 


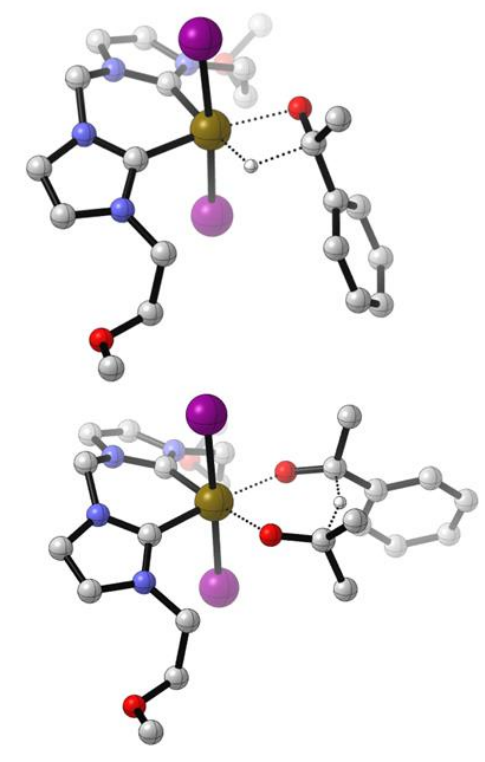

Figure 7. Geometrical representation of the optimized geometries of TSC/D (up) and TSA/D (down) for catalyst $\mathbf{5}$. Hydrogen atoms omitted for clarity.

\section{Conclusions}

A range of iridium(III) bis-NHC complexes with various ligand systems have proved to be active for the transfer hydrogenation of ketones and imines using 2-propanol as hydrogen source. The activity and stability of these pre-catalysts depends to a great extent on the nature of the wingtip groups at the NHCs and the apical ligands. Noteworthy, the most active catalyst is that featuring a bis-NHC ligand containing strongly coordinating moieties at the wingtip groups (5), which, at the same time, could be postulated also as the most stable complex in the light of the results obtained from the reusability experiments. Theoretical calculations at the DFT level support that the reaction proceeds by a stepwise monohydride mechanism. The alternative Meerwein-Ponndorf-Verley (MPV) pathway has been discarded by reason of the high energy barrier obtained for the hydride transfer via the consequent six-membered pericyclic transition state.

The first step of the proposed catalytic cycle requires the coordination of the isopropoxide at one of the equatorial positions (trans to the NHCs). $\beta$-Elimination affords then a hydrido and an acetone ligand, both trans to the NHCs. The high trans effect of the carbenes forces the migration of the hydride to the apical position and the iodide (or trifluoroacetate) to the equatorial position. Subsequently, the acetone ligand is replaced by the substrate and the hydride migrates again to the equatorial plane to give the migratory insertion of the $\mathrm{C}=\mathrm{X}(\mathrm{X}=\mathrm{N}, \mathrm{O})$ bond into the $\mathrm{Ir}-\mathrm{H}$ bond. Finally, the resulting alkoxide is protonated according to a concerted mechanism by a molecule of 2-propanol, which coordinates at the cis-positioned vacant site generated after the migratory insertion step.

The proposed mechanism agrees well with the different reactivity obtained experimentally for complexes 5 and 7, which present two iodides (5) or an iodide and a trifluoroacetate (7) in the apical positions. The replacement of $\mathrm{I}^{-}$by $\mathrm{CF}_{3} \mathrm{COO}^{-}$leads to a stabilization of the hydride intermediates and to the consequent increment of the overall activation energy.

As a final remark, this study sheds light on the nature of the hitherto unknown intermediate species involved in the mechanism that operates in the transfer hydrogenation reaction catalysed by iridium(III) Bis-NHC complexes and, furthermore, discloses the role played by all the ligands in the coordination sphere throughout the catalytic cycle.

\section{Experimental Section}

Experimental Details

All the manipulations were performed using standard Schlenk techniques under an argon atmosphere. All complexes after their formation were treated under aerobic conditions. Complex 
$[\operatorname{Ir}(\mathrm{COD}) \mathrm{Cl}]_{2}, \quad\left[\operatorname{Ir}\left(\square^{2} \mathrm{O}, \mathrm{O}^{\prime}-\mathrm{CH}_{3} \mathrm{COO}\right)(\mathrm{I})_{2}\left\{\kappa \mathrm{C}, \mathrm{C}^{\prime}-\mathrm{bis}\left(\mathrm{NHC}^{\mathrm{Me}}\right)\right\}\right] \quad(\mathbf{1}), \quad\left[\operatorname{Ir}\left(\mathrm{CH}_{3} \mathrm{CN}\right)_{2}(\mathrm{I})_{2}\left\{\kappa^{2} \mathrm{C}, \mathrm{C}^{\prime}-\right.\right.$ $\left.\left.\operatorname{bis}\left(\mathrm{NHC}^{\mathrm{R}}\right)\right\}\right]\left(\mathrm{BF}_{4}\right)\left(\mathrm{R}=n-\mathrm{Bu}(\mathbf{3}),-\mathrm{CH}_{2} \mathrm{CH}_{2} \mathrm{OPh}(\mathbf{4})\right), \quad\left[\operatorname{Ir}(\mathrm{I})_{2}\left\{\kappa^{4} \mathrm{C}, \mathrm{C}^{\prime}, \mathrm{O}, \mathrm{O}^{\prime}-\operatorname{bis}\left(\mathrm{NHC}^{\mathrm{OMe}}\right)\right\}\right]\left(\mathrm{BF}_{4}\right)$ $\left(\mathrm{OMe}=-\mathrm{CH}_{2} \mathrm{CH}_{2} \mathrm{OMe}\right)(5)$ were synthesised according to literature methods. ${ }^{[15]}$ 2-Propanol of analytical grade used as hydrogen donor was dried with Molecular Sieves and degassed prior to use. NMR spectra were recorded on Bruker Avance $400.16 \mathrm{MHz}$ spectrometer. Chemical shifts are given as dimensionless $\delta$ values and are frequency referenced relative to residual solvent peaks for ${ }^{1} \mathrm{H}$ and ${ }^{13} \mathrm{C}$ and to an external reference of $\mathrm{CFCl}_{3}$ for ${ }^{19} \mathrm{~F}$. All coupling constants $J$ are given in Hertz and multiplicity of the signals is indicated as $s$, singlet; $d$, doublet; $\mathrm{t}$, triplet; q, quartet; $\mathrm{m}$, multiplet. Carbon, hydrogen and nitrogen analysis were performed using a Perkin-Elmer 2400 microanalyzer. The substrates were obtained from common commercial sources and used as received. Air sensitive compounds were stored and weighed in glovebox. All experiments have been carried out under argon atmosphere.

\section{General Procedure for Transfer Hydrogenation Catalysis}

A solution of the corresponding catalyst precursor $(0.01 \mathrm{mmol})$ and $t \mathrm{BuOK}(5.6 \mathrm{mg}, 0.05 \mathrm{mmol})$ in dry 2-propanol $(5 \mathrm{~mL})$ was prepared under argon in a $25 \mathrm{~mL}$ schlenk flask. The solution was heated to $353 \mathrm{~K}$ for $15 \mathrm{~min}$ in a thermostated oil bath before the addition of ketone or imine $(1 \mathrm{mmol})$ and the internal standard (mesitylene, $140 \mu \mathrm{L}, 1 \mathrm{mmol}$ ). The resulting mixture was stirred at $353 \mathrm{~K}$ for $24 \mathrm{~h}$ or until complete conversion. Aliquots $(0.5 \mathrm{~mL})$ were taken at fixed times, quenched in tetrahydrofuran $(1 \mathrm{~mL})$ and filtered through a short path of $\mathrm{SiO}_{2}$. Yields were determined by GC analysis of reaction mixtures using an Agilent Technologies 7890A. Column: Agilent J\&W HP-5, $0.25 \mathrm{~mm} \times 30 \mathrm{~m} \times 0.25 \mu \mathrm{m}$. Substrates identities were determined by NMR spectroscopy and GCMS analysis using an Agilent Technologies 7890A system with an Agilent Technologies 5975C inert MS detector. Column: Agilent J\&W DB-1.

\section{General Procedure for Recycling Experiments}

The reactions were performed analogously to the procedure described above. After every cycle a new $1 \mathrm{mmol}$ of ketone was added and $0.05 \mathrm{mmol} t \mathrm{BuOK}$ were added.

\section{Synthesis of $\left[\operatorname{Ir}\left(\mathrm{CF}_{3} \mathrm{COO}\right) \mathbf{I}\left\{\boldsymbol{\kappa}^{4} \mathrm{C}_{\mathbf{3}} \mathrm{C}^{\prime}, \mathrm{O}, \mathrm{O}^{\prime}-\mathrm{bis}\left(\mathrm{NHC}^{\mathrm{OMe}}\right)\right\}\right]\left(\mathrm{BF}_{4}\right)$}

The title compound was prepared using complex $\left[\operatorname{Ir}(\mathrm{I})_{2}\left\{\kappa^{4} \mathrm{C}, \mathrm{C}^{\prime}, \mathrm{O}, \mathrm{O}^{\prime}-\right.\right.$ bis $\left.\left.\left(\mathrm{NHC}^{\mathrm{OMe}}\right)\right\}\right] \mathrm{BF}_{4}$ as starting material. A solution of $\mathrm{CF}_{3} \mathrm{COOAg}(45.5 \mathrm{mg}, 0.22 \mathrm{mmol}$; dry acetone, $30 \mathrm{~mL})$ was added under dropwise an argon atmosphere at room temperature to a solution of the cited compound (160.0 mg, $0.20 \mathrm{mmol})$ in dry acetone $(30 \mathrm{~mL})$. The suspension was stirred for $1 \mathrm{~h}$ in the absence of light. The $\mathrm{AgI}$ formed was separated by filtration and the filtrate was partially concentrated under reduced pressure. Slow addition of diethyl ether $(15 \mathrm{~mL})$ afforded a light brown solid. The new compound was filtered, washed with diethyl ether $(3 \times 15 \mathrm{~mL})$ and dried under vacuum. Yield: $72 \%(106.5$ $\mathrm{mg}, 0.14 \mathrm{mmol}) .{ }^{1} \mathrm{H}$ NMR $(400 \mathrm{MHz}$, Acetone-d 6$): \delta 7.61\left(\mathrm{~d}, J_{\mathrm{H}-\mathrm{H}}=2 \mathrm{~Hz}, 2 \mathrm{H}, \mathrm{CH} H_{\mathrm{im}}\right), 7.52\left(\mathrm{~d}, J_{\mathrm{H}-\mathrm{H}}\right.$ $\left.=2 \mathrm{~Hz}, 2 \mathrm{H}, \mathrm{CH}_{\mathrm{im}}\right), 6.77\left(\mathrm{~d}, J_{\mathrm{H}-\mathrm{H}}=13 \mathrm{~Hz}, 1 \mathrm{H}, \mathrm{NCH}_{2} \mathrm{~N}\right), 6.64\left(\mathrm{~d}, J_{\mathrm{H}-\mathrm{H}}=13 \mathrm{~Hz}, 1 \mathrm{H}, \mathrm{NCH}_{2} \mathrm{~N}\right), 4.72-$ $4.49\left(\mathrm{~m}, 8 \mathrm{H}, \mathrm{NCH}_{2}\right.$ y $\left.\mathrm{CH}_{2} \mathrm{O}\right), 4.14\left(\mathrm{~s}, 6 \mathrm{H}, \mathrm{CH}_{3} \mathrm{O}\right) .{ }^{13} \mathrm{C}$ NMR $\left(101 \mathrm{MHz}\right.$, Acetone-d $\left.\mathrm{d}_{6}\right): \delta 161.0(\mathrm{q}$, $\left.{ }^{2} J_{\mathrm{C}-\mathrm{F}}=37 \mathrm{~Hz}, \mathrm{CF}_{3} C \mathrm{OO}\right), 123.5\left(C \mathrm{H}_{\mathrm{im}}\right), 121.4\left(C \mathrm{H}_{\mathrm{im}}\right), 120.2\left(, \mathrm{NC}_{\mathrm{im}} \mathrm{N}\right), 113.6\left(\mathrm{q},{ }^{1} J_{\mathrm{C}-\mathrm{F}}=293 \mathrm{~Hz}\right.$, $\left.\mathrm{CF}_{3} \mathrm{COO}\right), 75.7\left(\mathrm{OCH}_{2}\right), 63.9\left(\mathrm{CH}_{3} \mathrm{O}\right), 61.7\left(\mathrm{NCH}_{2} \mathrm{~N}\right), 47.8\left(\mathrm{CH}_{2} \mathrm{~N}\right) .{ }^{19} \mathrm{~F}$ NMR (Acetone-d $\mathrm{d}_{6}, 282$ $\mathrm{MHz}): \delta-151.4\left(\mathrm{~s}, 4 \mathrm{~F}, \mathrm{BF}_{4}\right), 74.8\left(\mathrm{~s}, 3 \mathrm{~F}, \mathrm{CF}_{3} \mathrm{COO}\right)$. Elemental analysis calcd (\%) for $\mathrm{C}_{15} \mathrm{H}_{20} \mathrm{BF}_{7} \mathrm{IIrN}_{4} \mathrm{O}_{4}$ (783.26): C 23.00, H 2.57, N 7.15; found: C 23.15, H 2.75, N 7.07.

Synthesis of $\left[\operatorname{Ir}\left(\mathrm{CH}_{3} \mathrm{CN}\right)_{2}(\mathrm{I})_{2}\left\{\boldsymbol{\kappa}^{2} \mathbf{C}, \mathrm{C}^{\prime}-\right.\right.$ bis $\left.\left.\left(\mathrm{NHC}^{\mathrm{Me}}\right)\right\}\right]\left(\mathrm{BF}_{4}\right)$

$\mathrm{HBF}_{4} \mathrm{Et}_{2} \mathrm{O}(96 \mu \mathrm{L}, 0.77 \mathrm{mmol})$ was added dropwise under argon to a solution of $\left[\operatorname{Ir}\left(\square^{2} \mathrm{O}, \mathrm{O}\right.\right.$ $\left.\mathrm{CH}_{3} \mathrm{COO}\right)(\mathrm{I})_{2}\left\{\kappa \mathrm{C}, \mathrm{C}^{\prime}-\right.$ bis $\left.\left.\left(\mathrm{NHC}^{\mathrm{Me}}\right)\right\}\right](0.50 \mathrm{~g}, 0.70 \mathrm{mmol})$ in dry $\mathrm{CH}_{2} \mathrm{Cl}_{2}(30 \mathrm{~mL})$ at $273 \mathrm{~K}$, after the addition the reaction mixture was stirred for $45 \mathrm{~min}$. Subsequently, $\mathrm{CH}_{3} \mathrm{CN}(5 \mathrm{~mL})$ was added and the reaction mixture stirred at room temperature for $45 \mathrm{~min}$. The solvent was evaporated under reduced pressure. The resulting residue was washed with diethyl ether $(3 \times 15 \mathrm{~mL})$ to give the title compound as an orange solid. Yield: $78 \%(432.4 \mathrm{mg}, 0.55 \mathrm{mmol}) .{ }^{1} \mathrm{H}-\mathrm{NMR}\left(\mathrm{CD}_{3} \mathrm{CN}, 400 \mathrm{MHz}\right): \delta$ $7.31\left(\mathrm{~d}, 2 \mathrm{H}, J_{\mathrm{H}, \mathrm{H}}=2.0 \mathrm{~Hz}, \mathrm{CH}_{\mathrm{im} \text { ext }}\right), 7.20\left(\mathrm{~d}, 2 \mathrm{H}, J_{\mathrm{H}, \mathrm{H}}=2.0 \mathrm{~Hz}, \mathrm{CH}_{\mathrm{im} \mathrm{int}}\right), 6.39\left(\mathrm{~s}, 2 \mathrm{H}, \mathrm{NCH}_{2} \mathrm{~N}\right), 4.04$ (s, 6H, $\left.\mathrm{NCH}_{3}\right), 2.09\left(\mathrm{~s}, 6 \mathrm{H}, \mathrm{CH}_{3} \mathrm{CN}\right) .{ }^{13} \mathrm{C}\left\{{ }^{1} \mathrm{H}\right\}-\mathrm{NMR}\left(\mathrm{CD}_{3} \mathrm{CN}, 100 \mathrm{MHz}\right): \delta 128.0\left(\mathrm{NC}_{\mathrm{im}} \mathrm{N}\right), 125.3$ $\left(\mathrm{CH}_{\text {im int }}\right), 122.4\left(\mathrm{CH}_{\text {im ext }}\right), 64.5\left(\mathrm{NCH}_{2} \mathrm{~N}\right), 40.9\left(\mathrm{NCH}_{3}\right)$. Elemental analysis calcd $(\%)$ for $\mathrm{C}_{13} \mathrm{H}_{18} \mathrm{BF}_{4} \mathrm{I}_{2} \mathrm{IrN}_{6}$ (791.15): C 19.74, H 2.29, N 10.62; found: C 20.02, H 2.38, N 10.53. 


\section{X-Ray Crystallography}

Crystal data, data collection and refinement parameters for compound 7 were collected on a Bruker Kappa APEX2 diffractometer equipped with an area detector and graphite monochromated Mo K $\alpha$ radiation $(0.71073 \AA)$. Data reduction was done with the APEX2 software. ${ }^{[16]}$ The structure was solved by direct methods and refined by full-matrix least-squares methods based on $F^{2}$ using SHELXL-97 and WinGX programs. ${ }^{[17]}$ Non-hydrogen atoms were refined anisotropically. $\mathrm{H}$ atoms were positioned geometrically and refined with isotropic displacement parameters according to the riding model. Distance and angle calculations were performed using the SHELXL-97 and WinGX programs. ${ }^{[17]}$ Refinement parameters for compound 7 are as follows: $\left[\mathrm{C}_{15} \mathrm{H}_{20} \mathrm{BF}_{7} \mathrm{IIrN} \mathrm{Ir}_{4} \mathrm{O}_{4}\right]$, triclinic, $P-1, a=8.7610(7) \AA, b=16.4845(13) \AA, c=16.5855(13) \AA, \alpha=69.8940(10)^{\circ}, \beta=85.3810(10)^{\circ}, \gamma$ $=80.4010(10)^{\circ}, Z=4, M_{\mathrm{r}}=783.26, V=2217.1(3) \AA^{3}, D_{\text {calcd }}=2.347 \mathrm{~g} \mathrm{~cm}^{-3}, \lambda($ Mo K $\alpha)=0.71073$ $\AA, \mathrm{T}=100 \mathrm{~K}, \mu=7.503 \mathrm{~mm}^{-1}, 26533$ reflections collected, 10173 unique $\left(R_{\text {int }}=0.0330\right), 8558$ observed, $R 1\left(F_{\mathrm{o}}\right)=0.0385[I>2 \sigma(I)], w R 2\left(F_{\mathrm{o}}{ }^{2}\right)=0.0879$ (all data), GOF $=1.037$. CCDC 1410334 .

\section{Computational details}

All calculations were done at the DFT level using the B3LYP approximation ${ }^{[18]}$ as implemented in the Gaussian program package. ${ }^{[19]}$ Dispersion corrections were added by the D3 scheme developed by Grimme ${ }^{[20]}$ for both energies and gradient calculations. The def2-SVP basis set ${ }^{[21]}$ has been selected for geometry optimizations and calculation of Gibbs energy corrections at $353.15 \mathrm{~K}$ and single point energy corrections were added using the def2-TZVP basis set and the PCM approach for simulation of the solvent effect. ${ }^{[22]}$ The nature of the stationary points has been confirmed by analytical frequency analysis, and transition states were characterized by a single imaginary frequency corresponding to the expected motion of the atoms.

\section{Acknowledgements}

The authors would like to acknowledge the support from the Ministry of Higher Education, Saudi Arabia, in establishment of the Center of Research Excellence in Petroleum Refining \& Petrochemicals at KFUPM. The support of KFUPM under the KACST funded project (ART-32-68) and the KFUPM-University of Zaragoza research agreement are also highly appreciated. This work was also supported by the Spanish Ministry of Economy and Competitiveness (MINECO/FEDER) (CONSOLIDER INGENIO CSD2009-0050, CTQ2011-27593 and CTQ2012-35665 projects) and the DGA/FSE-E07. V. P. thankfully acknowledges the resources from the supercomputer "Memento", technical expertise and assistance provided by BIFI-ZCAM (Universidad de Zaragoza).

Keywords: Iridium $\bullet \mathrm{NHC} \bullet$ carbene $\bullet$ catalysis $\bullet$ transfer hydrogenation

\section{References}

[1] a) H. Blaser, C. Malan, B. Pugin, F. Spindler, H. Steiner, M. Studer, Adv. Synth. Catal. 2003, 345, 103; b) R. Noyori Asymmetric Catalysis in Organic Synthesis, Wiley-VCH, Weinheim, 1994; c) L. A. Oro, in Encyclopedia of Catalysis, Vol. 4 (Eds. I. V. Horváth, E. Iglesia, M. T. Klein, J. A. Lercher, A. J. Rusell and E. I. Stiefel) Jonh Wiley \& Sons, pp. 55.

[2] a) D. Klomp, U. Hanefeld, J. A. Peters, in The Handbook of Homogeneous Hydrogenation, Vol. 3 (Eds.: J. G. de Vries, C. J. Elsevier), Wiley-VCH: Weinheim, 2007, pp. 585; b) G. Brieger,T. J. Nestrick, Chem. Rev. 1974, 74, 567; c) D. Wang, D. Astruc, Chem. Rev. DOI: 10.1021/acs.chemrev.5b00203.

[3] a) A. C. Hillier, H. M. Lee, E. D. Stevens, S. P. Nolan, Organometallics 2001, 20, 4246; b) O. Saidi, J. M. J. Williams, Top. Organomet. Chem. 2011, 34, 77; c) S. C. Zinner, C. F. Rentzsch, E. Herdtweck, W. A. Herrmann, F. E. Kühn, Dalton Trans. 2009, 7055.

[4] a) M. Albrecht, J. R. Miecznikowski, A. Samuel, J. W. Faller,R. H. Crabtree, Organometallics 2002, 21, 3596; b) J. R. Miecznikovski, R. H. Crabtree, Polyhedron 2004, 23, 2857; c) J. R. Miecznikovski, R. H. Crabtree, Organometallics 2004, 23, 629; d) E. Peris, R. H. Crabtree, Coord. Chem. Rev. 2004, 248, 2239. 
[5] S. Gladiali, G. Mestroni, in Transition Metals for Organic Synthesis, Vol. 2 (Eds.: M. Beller, C. Bolm), Wiley-VCH: Weinheim, Germany, 1998, pp. 97-119.

[6] a) H. Meerwein, R. Schmidt, Justus Liebigs Annalen der Chemie 1925, 444, 221; b) W. Ponndorf,. Angew. Chem. 1926, 39, 138; c) Verley, A. Bull. Soc. Chim. Fr. 1925, 37, 537; d) C. F.de Graauw, J. A. Peters, H. van Bekkum, J. Huskens, Synthesis 1994, 10, 1007; e) G. K. Chuah, S. Jaenicke, Y. Z. Zhu, S. H. Liu, Curr. Org. Chem. 2006, 10, 1639.

[7] O. Pàmies, J.-E. Bäckvall, Chem. Eur.J. 2001, 7, 5052.

[8] W. von E. Doering, T. C.Aschner, J. Am. Chem. Soc. 1954, 75, 393.

[9] a) M. Iglesias, M. Pérez-Nicolás, P. J. Sanz Miguel, V. Polo, F. J. Fernández-Alvarez, J. J. Pérez-Torrente, L. A. Oro, Chem. Commun. 2012, 48, 9480; b) M. Iglesias, P. J. Sanz Miguel, V. Polo, F. J. Fernández-Alvarez, J. J. Pérez-Torrente, L. A. Oro, Chem. Eur. J. 2013, 19, 17559; c) M. Iglesias, F. J. Fernández-Alvarez, L. A. Oro, ChemCatChem 2014, 6, 2486; d) M. Iglesias, M. Aliaga-Lavrijsen, P. J. Sanz Miguel, F. J. Fernández-Alvarez, J. J. Pérez-Torrente, L. A. Oro, Adv. Synth. Catal. 2015, 357, 350; e) M. Aliaga-Lavrijsen, M. Iglesias, A. Cebollada, K. Garcés, N. García, P. J. Sanz Miguel, F. J. Fernández-Alvarez, J. J. Pérez-Torrente, L. A. Oro, Organometallics, Organometallics 2015, 34, 2378.

[10] a) A. Binobaid, M. Iglesias, D. J. Beetstra, B. Kariuki, A. Dervisi, I. A. Fallis, K. J. Cavell, Dalton Trans., 2009, 7099; b) M. V. Jiménez, J. J. Pérez-Torrente, M. I. Bartolomé, V. Gierz, F. J. Lahoz, L. A. Oro, Organometallics, 2008, 27, 224; c) M. V. Jiménez, J. Fernández-Tornos, J. J. Pérez-Torrente, F. J. Modrego, S. Winterle, C. Cunchillos, F. J. Lahoz, L. A. Oro, Organometallics, 2011, 30, 5493; d) M. V. Jiménez, J. Fernández-Tornos, J.J. Pérez-Torrente, F. J. Modrego, P. García-Orduña, L. A. Oro, Organometallics 2015, 34, 926.

[11]As previously reported by us in reference 6e, phenyl ethyl ether N-substituted NCH ligands behave as hemilabile ligands. The oxygen atoms of the phenyl ethyl ether wingtip groups are coordinating and dissociating in solution at room temperature. On the other hand, NHCs featuring methyl ethyl ether on the peripheral nitrogen atoms are strongly coordinating tetratopic ligands.

[12] A. Binobaid, M. Iglesias, D. Beetstra, A. Dervisi, I. Fallis, K. J. Cavell, Eur. J. Inorg. Chem. 2010, 5426 .

[13] A. Comas-Vives, G. Ujaque, A. Lledós J. Molec. Struc.-Theochem 2009, 903, 123.

[14]a) O. Pàmies, J.-E. Bäckvall, Chem. Eur. J. 7 (2001) 5052. b) A. Aranyos, G. Csjernyik, K.J. Szabó, J.-E. Bäckvall, Chem. Commun. (1999) 351; c) A. Comas-Vives, G. Ujaque, A. Lledós, Organometallics 2007, 26, 4135.

[15]G. Giordano, R. H. Crabtree, R. M. Heintz, D. Forster, D. E. Morris, Inorganic Synthesis Reagents for Transition Metal Complexes and Organometallic Synthesis, 1990, 28, 88.

[16]APEX2 Bruker AXS Inc., Madison, Wisconsin, USA, 2011.

[17] a) G. M. Sheldrick, SHELXS-97 and SHELXL-97; University of Göttingen, Germany, 1997; b) L. J. Farrugia, Win $G X$; University of Glasgow, Great Britain, 1998.

[18] a) C. Lee, W. Yang, R. G. Parr, Phys. Rev. B, 1988, 37, 785-789; b) A. D. Becke, J. Chem. Phys. 1993, 98, 1372-1377; c) A. D. Becke, J. Chem. Phys. 1993, 98, 5648-5652.

[19] Gaussian 09, Revision D.01. Wallingford CT, 2009.

[20] S. Grimme, J. Antony, S. Ehrlich, H. Krieg, J. Chem. Phys. 2010, 132, 154104.

[21]F. Weigend and R. Ahlrichs, Phys. Chem. Chem. Phys. 2005, 7, 3297-3305.

[22] J. Tomasi, B. Mennucci, R. Cammi, Chem. Rev. 2005, 105, 2999-3094. 